\title{
Ještě ke smlouvě o dílo
}

\author{
Karel Marek *
}

DOI: https://doi.org/10.24040/sap.2021.8.4.238-267

\begin{abstract}
Abstrakt
MAREK, Karel: Ještě ke smlouvě o dílo. V souvislosti s rozvojem průmyslu, s průmyslovou revoluci 4.0 a odstraňováním následků koronakrize, lze očekávat rozvoj investic. $\mathrm{K}$ tomu bude využíváno smluvního typu smlouvy o dílo. Důvodová zpráva zpracovaná $\mathrm{k}$ občan. zák. uvádí, že nová úprava díla (podle $\S$ 2586 - 2635 občan. zák.) má odstranit dualismus úpravy neobchodní a obchodní smlouvy o dílo. Za základ návrhu nové úpravy byla vzata úprava obchod. zák. $\mathrm{s}$ přihlédnutím $\mathrm{k}$ některým zahraničním úpravám, protože pojetí smlouvy o dílo $\mathrm{v}$ dřívějším občanském zákoníku bylo poplatné jeho původní koncepci z r. 1964 a vzoru občanského zákoníku z r. 1950. V určitých směrech se přihlíží i k některým ustanovením někdejšího zákoníku mezinárodního obchodu (ZMO), jehož normativní konstrukce obchodní zákoník přejímal, ale které byly často formulovány přesněji a přehledněji ZMO. Aktuálním otázkám smlouvy o dílo se věnuje toto pojednání.
\end{abstract}

\section{Kličová slova:}

obchodní zákoník, občanský zákoník, závazky, smlouvy, smlouva o dílo

\section{More to the Work Contract}

\begin{abstract}
:
MAREK, Karel: More to the Work Contract. In connection with the development of industry, the industirial revolution 4.0 and the elimination of the consequences of the coronary crisis, the development of investment can be expected. Reasonable report processed for the citizen. disciple. states that the new adaptation of the work (according to $\S 2586-2635$ of the Civil Code) is intended to eliminate the dualism of the regulation of the non-commercial and commercial contract of work. Based on the draft of the new regulation, the deal was adopted. disciple. taking into account some foreign modifications, since the concept of a contract of work in the valid Civil Code was subject to its original concept of 1964 and to the model of the 1950 Civil Code. In some respects, some provisions of the former International Trade Code (ZMO) the normative structure of which was adopted by the Commercial Code, but which were often formulated more precisely and more clearly in the ZMO. The works contract deals with this treatise.
\end{abstract}

\section{Key words:}

business code, civil code, obligations, contracts, contract for work

* Prof. JUDr. Karel Marek, CSc. - Fakulta právních a správních studií, Vysoká škola finanční a správní Praha. 


\section{Obecně}

V souvislosti s rozvojem průmyslu, průmyslovou revolucí 4.0 a odstraňováním následků koronakrize, lze očekávat rozvoj investic. $Z$ toho důvodu se text také snaží orientovat na technologické dodávky, které by měly být rozhodující, i když se též věnujeme problematice širší. Tyto dodávky budou vyžadovat smluvní zabezpečení za pomoci smluvních typů občan. zák., ale i za pomoci nepojmenovaných smluv. Začasté se však budou uzavírat smlouvy kupní a zejména i smlouvy o dílo. Navazujme proto na svoje dřívější publikace $\mathrm{k}$ tomuto tématu a zaměřujeme se na nadepsanou tématiku.

Důvodová zpráva zpracovaná k občan. zák. uvádí, že nová úprava díla (podle $§ 2586$ - 2635 občan. zák.) má odstranit dualismus úpravy neobchodní a obchodní smlouvy o dílo. Za základ návrhu nové úpravy byla vzata úprava obchod. zák. s přihlédnutím k některým zahraničním úpravám, protože pojetí smlouvy o dílo v platném občanském zákoníku bylo poplatné jeho původní koncepci z r. 1964 a vzoru občanského zákoníku z r. 1950. V určitých směrech se přihlíží i k některým ustanovením někdejšího zákoníku mezinárodního obchodu (ZMO), jehož normativní konstrukce obchodní zákoník přejímal, ale které byly často formulovány přesněji a přehledněji ZMO.

I když došlo ke „sjednocení“ právní úpravy, je třeba si uvědomit specifikum, že pro vztahy mezi podnikateli se zásadně použijí obchodní zvyklosti před dispozitivními ustanoveními občan. zák. (pokud to smluvní ujednání nevyloučí).

Dílo je pojato standardně jako činnost (práce), přičemž práce jako plnění smlouvy o dílo se od práce poskytované zaměstnancem na základě pracovní smlouvy liší zejména tím, že podle smlouvy o dílo vykonává zhotovitel činnost samostatně, podle vlastního rozvrhu, s vlastními prostředky a na vlastní riziko, nepodléhaje zásadně ani soustavnému dozoru, ani řízení objednatele. K tomu je možno uvést, že je přitom celá řada prŕípadů, kdy však je prováděn průběžně technický dozor objednatele (např̀. právě ve výstavbě).

Zhotovitel provádí dílo osobně nebo je nechává provést pod svým osobním vedením jen tehdy, je-li to zapotřebí vzhledem k jeho osobním vlastnostem nebo k povaze díla. Nejedná-li se o takový př́pad, může zhotovitel pověřit provedením nebo vedením díla jinou osobu, pak však odpovídá za řádné plnění jako by dílo provedl sám.

Velmi často je k provedení díla potřebná součinnost objednatele v různých formách (dostavit se ke zkoušce šatů šitých na míru, předat věc k provedení opravy, umožnit vstup do domu nebo bytu, předat staveniště atp.). Občan. zák. řeší na obecné úrovni různé aspekty těchto situací. Zhotovitel není př́ikazníkem objednatele, nepodléhá tudíž zásadně jeho pokynům, může to však být v určitém rozsahu ujednáno. Stejně tak může (a někdy pro určité případy musí) být ujednáno, že objednatel dodá zhotoviteli věc nebo materiál k provedení díla apod. Pro tyto případy je převzato řešení, že zhotovitel jako osoba, která dílo provádí na svoji odpovědnost, musí případné prríkazy objednatele stejně jako věci případně objednatelem k provedení díla předané s dostatečnou péčí prověřit a upozornit na jejich př́ípadné vady.

Řešena je i situace, kdy objednatel, ač k tomu smluvně zavázán, věc, kterou měl zhotoviteli dodat jako protiplnění, nedodá. 
Právě proto, že je pravidlem, že zhotovitel při provádění díla příkazům objednatele nepodléhá, musí zákon vyhradit objednateli právo kontroly nad prováděním díla. $\mathrm{V}$ tom směru se přjímá dosavadní pojetí občan. zák. a obchod. zák. a objednatel právo kontroly má.

Povinnost provést dílo zhotovitel splní jeho dokončením a předáním, své povinnosti objednatel splní převzetím a zaplacením ceny. Řeší se také ty zvláštní prrípady, kdy je dílo předáváno po částech, kdy je cena určena jen odhadem, kdy je dílo z různých př́ičin zmařeno apod.

Pokud jde o vady díla, odkazuje se shodně s dřivějšími úpravami na přiměřená použití ustanovení o kupní smlouvě.

Dnes jde u smlouvy o dílo o činnost, která nemusí hmotně zachycená.

Protože nová právní úprava vychází z dosavadní úpravy obchodněprávní, může být více přijatelná pro podnikatelskou než pro občanskou sféru.

Smlouva o dílo se začasté využívá právě ve výstavbě, kde je východiskem zvládnutí pojmového aparátu, který se vytvořil a kde použití příslušného pojmu s jeho daným obsahem, začasté vytvořeným jako obchodní zvyklost, může být východiskem pro stanovení povinnosti některé ze smluvních stran. Proto se věnujeme nejprve těmto otázkám.

Stavbou se rozumí stavební dílo bez zřetele na jeho stavebně technické provedení, účel a dobu trvání. Kromě jednoduchých či liniových staveb, a to zvláště u staveb průmyslových, se stavba pravidelně člení na: stavební část stavby (která však zahrnuje i jiné než stavební dodávky, a to ty dodávky, které do stavební části přísluší, např. světelné elektroinstalace, zdravotní techniku, rozvody vytápění apod.) a technologickou část stavby (nazývanou též strojnětechnologickou částí stavby).

\section{1 Členění stavby}

Stavební část stavby členíme na stavební objekty. Stavební objekt je definován jako prostorově ucelená část stavby, která je její základní částí.

Stavební část se člení prostorově. Technologická část se sestává u prvků vytvořených funkčně.

Provozní celek (PC) je v technologické části souhrn vzájemně funkčně navazujících provozních souborů, vykonávající úplný technologický proces, popř. úplný technologický proces speciální, a to jednoho druhu, určený dokumentací stavby a uváděný do provozu zpravidla v souvislém čase. Provozní celek je v hlavních rysech charakterizován druhem procesu, pro který je pořizován.

Provozní celek se člení na provozní soubory, a to obvykle na několik provozních souborů strojního, elektrotechnického a dalšího zařízení pro základní technologický proces (resp. technologický proces speciální) a $\mathrm{z}$ dalších provozních souborů pro doplňkově technologické procesy. Za provozní celek se považují úplná technologická zařízení napřr. pro strojírenský závod či úpravnu odpadních vod.

U složitých výrobních staveb je možno provozní celek členit na dílčí provozní celky. Provozní celek těchto staveb je charakterizován kompletností technologie od vstupu surovin, polotovarů a jiných materiálů určených ke zpracování až po výstup finálních výrobků, prrípadně včetně balení a expedice. 
Dílčí provozní celek (DPC) je souhrn vzájemně funkčně navazujících provozních souborů, vykonávající dílčí část úplného technologického procesu, popř̀. dílčí část úplného technologického procesu speciálního, určený dokumentací stavby a uváděný do provozu zpravidla v souvislém čase.

Také dílčí provozní celek se člení na provozní soubory; u výrobních staveb je charakterizován uzavřeným technologickým procesem, který je na vstupu a výstupu obvykle ukončen jeho částečným přerušením (mezisklad, silo, skládka atd.). Při návrhu členění je třeba vycházet ze zajištění komplexnosti funkce příslušného dílčího provozního celku tak, aby bylo možno zajistit provádění samostatných komplexních vyzkoušení dílčích provozních celků a jejich postupné předávání a přípravu pro následný zkušební provoz (a garanční zkoušky).

Provozní soubor (PS) je funkčně ucelená část provozního celku, dílčího provozního celku nebo technologické části stavby (soubor strojů a zařízení tvořící samostatný funkční celek), tvořená souhrnem technologických zařízení, vykonávající ucelený dílčí technologický, tj. samostatný proces, popř. technologický speciální proces, nebo úplný technologický proces doplňkový, určená dokumentací stavby a uváděná do provozu zpravidla v souvislém čase.

Provozní soubor se zpravidla člení na provozní jednotky nebo na provozní jednotky a základní jednotky anebo přímo na základní jednotky. Pokud je to účelné (např. pro dodavatelské zajištění stavby), člení se provozní soubor na dílčí provozní soubory.

Dílčí provozní soubor (DPS) je funkčně ucelená část provozního souboru, tvořená souhrnem technologických zařízení a vykonávající samostatný dílčí technologický proces (popř. technologický proces speciální nebo doplňkový), určená dokumentací stavby a uváděná do provozu zpravidla v souvislém čase. Používá se jen výjimečně u velmi členitých a složitých zařízení, kdy mezi provozní soubor a provozní jednotku je účelné nebo potřebné vložil další mezistupeň. Člení se na provozní jednotky nebo na provozní jednotky a základní jednotky anebo přímo na základní jednotky.

Provozní jednotka (PJ) je funkčně ucelená část provozního souboru nebo dílčího provozního souboru, tvořená souhrnem technologických zařízení a vykonávající ucelenou část dílčího technologického procesu určeného dokumentací stavby.

Provozní jednotka se může členit na základní jednotky. Funkční skladba provozní jednotky se stanoví v dokumentaci stavby a její funkci lze ověřit jen současným vyzkoušením všech základních jednotek ji tvořících.

Základní jednotka (ZJ) je výrobek zpravidla dodávaný jedním výrobcem, který má jako celek samostatné určení, plní určitou vymezenou a trvalou provozně technickou funkci hlavní nebo pomocnou a tvoří konstrukčně uzavřenou jednotku, kterou nelze beze zbytku rozdělit na dvě nebo více funkčních jednotek. Základní jednotka se v dokumentaci stavby dále nečlení. Pojem základní jednotka má v podstatě charakter tzv. kusové dodávky, jde o označení samostatného stroje nebo zařízení.

Způsob realizace výstavby lze rozlišovat podle toho, jakou měrou přispívají účastníci k realizaci stavby. Tedy jaký je dodavatelský systém. Dodavatelský systém určuje, které subjekty jsou v prŕmém vztahu k investorovi, či ve vztahu k jiným subjektům, a jakým zpo̊sobem dodávají. Může jít o různé druhy dodávek.

Generální dodávka vychází z rozsahu celé stavební části stavby či technologické části stavby. U technologické části stavby vychází z úrovně provozního celku. Finální 
dodávka je dodávka na úrovni provozního souboru a finální poddodávka na úrovní dílčího provozního souboru.

Pokud se jedná o stroj (stroje), zařízení, které jsou současně dodávány, montovány a odzkoušeny, funkci (technologického či netechnologického) procesu nezajišt'ující, jde o tzv. dodávku smontovaných strojů.

Zvláště z hlediska praxe má pochopitelně význam označení a definování provozně nevyzkoušených strojů a zařízení. Provozně nevyzkoušené stroje a zařízení jsou specifické tím, že jsou dodávány na stavbu, aniž bylo možno předtím plně ověřit jejich funkceschopnost v podmínkách, které odpovídají konkrétním provozním podmínkám dané stavby.

Dodávkami na klíč se pak rozumí dodávky celé stavby (tj. stavební části a technologické části). ${ }^{1}$

\section{2 Účastníci výstavby}

Investorem je označena osoba, která stavbu pro sebe nebo pro jiného připravuje a zajišt'uje. Jde o subjekt uzavírající pro přípravu a realizaci stavby smlouvy s dalšími účastníky výstavby.

Pokud není investor vhodně procesně vybaven (nemá vnitřní kvalifikovaný útvar či pracovníky potřebných odborností), může pro něj investorské činnosti vykonávat specializovaný subjekt (např. tzv. inženýrské nebo projektově - inženýrské organizace), např. na základě př́kazní smlouvy či tzv. nepojmenované smlouvy o investorské činnosti.

Pod pojmem dodavatelé pak rozumíme osoby, které zabezpečují (provádějí) dodávky pro stavbu, at' již na základě smlouvy o dílo či jiných smluv.

V tomto rámci jsou i vyšší dodávky a jim odpovídající vyšší dodavatelé, tj. generální dodavatelé (na úrovni stavební části či provozního celku), finální dodavatelé (na úrovni provozního souboru), finální poddodavatelé (na úrovni dílčího provozního souboru).

Kusové dodávky jsou dodávky zboží podle smluv kupních nebo dílčích montáží podle smlouvy o dílo, jejich dodavatelé (prodávající, zhotovitelé) nesou označení kusoví dodavatelé.

Profesními dodávkami se přitom rozumí dodávky, které zajištuje dodavatel pro všechny části provozního celku či provozního souboru podle přísl. profese (např. elektroinstalace silnoproudu).

Vytváří se přitom zejména dodavatelské systémy generálních dodávek vč. Dodávek na klíč a „conctruction management“ (dílo rozděleno do tzv. balíčků).

\subsection{Dokumentace stavby}

Dokumentace stavby je prritom takový souhrn dokladů, které se pro stavbu zpracovávají v souladu s funkcemi, které budou plnit.

$\mathrm{V}$ prvé etapě (fázi) jde o dokumentaci při př́pravě investice, tj. před fází zpracování jednotlivých stupňů ,projektové dokumentace“ (tzv. předinvestiční fáze). Jde

1 K obchodním zvyklostem např. viz KRÁLOVÁ, K. - MAREK, K. Obchodní podmínky, vykládací pravidla a obchodní zvyklosti. In Acta Iuridica Sladkoviciensia XVII, 2021, s. 135152, ISBN 978-80-7392-363-1. 
zpravidla o zpracování technicko - ekonomické studie nebo studie souboru staveb. Studie především definuje cíle projektu (ve věcném i ekonomickém a časovém vyjádření) a prokazuje na koncepční úrovni vhodnost (ve variantách řešení zohledňujících i umístění stavby v území a krajině), že navržených a doporučených cílů investičního záměru - projektu lze dosáhnout. Slouží rozhodnutí orgánů investora, zda projekt ( $\mathrm{k}$ dosažení navržených cílů - záměru projektu) bude (či nebude) realizován, a pokud ano, pak ve které z koncepčních variant navržených ve studii (z nichž jedna byla osobou zpracovatele studie doporučena).

Ve druhé etapě (fázi) se pravidelně zpracovávají jednotlivé stupně potřebné projektové dokumentace:

- Dokumentace přikládaná k návrhu na vydání rozhodnutí o umístění stavby (DÚR)

- Dokumentace přikládaná k žádosti o vydání stavebního povolení (DSP)

- Dokumentace pro provedení stavby (DPS)

Mimo tyto stupně projektové dokumentace bývá zpracována:

- Realizační dokumentace stavby (RP); zpracovává se pravidelně zhotovitelem

- Dokumentace (výkresy) skutečného provedení stavby; zpracovává se vždy

- Dokumentace pro výběr zhotovitele (DVZS); zpracovává se podle potřeby, zejména jde-li o veřejné zakázky

- Koncepční projekt pro technologickou část stavby $(\mathrm{KP})$ je zpracován jen v případě potřeby, tj. pro podrobnější vyjasnění navrhovaných technologických procesů v etapě, kdy bude teprve posléze vypracována DSP (KP podle zvyklostí a podle požadavků stavebních úrúadů neobsahuje podrobnější řešení technologické části stavby), tedy před zahájením prací na DPS tak, aby toto vyjasnění bylo pro zpracovatele DPS již závazné. Tento př́ípad je žádoucí tehdy, když projekt pro provedení stavby (DPS) zpracovává př́mo vybraný zhotovitel.

Pokud pro stavbu není třeba stavební povolení, ale stačí jen její ohlášení, zpracovává se dokumentace $\mathrm{k}$ ohlášení stavby (DOS).

U všech staveb pochopitelně nemusí být vždy zpracovány všechny druhy a stupně dokumentace a některý druh dokumentace může plnit více funkcí (v některých príípadech za určených podmínek se př́sl.dokumentace nezpracovává).

\subsection{Zkoušky}

Ve smlouvě bychom neměli opomenout ani ujednání o zkouškách a splnění závazku. Zkouškami se ověřují vlastnosti zkoušených plnění a jejich způsobilost. Existují různé druhy zkoušek, od technicky poměrně jednoduchých až po zkoušky odborně velmi složité.

Zkoušky jsou zpravidla vymezeny i právními předpisy, technickými předpisy či technickými normami. Zejména jsou však (vč. obsahu) dohodnuty ve smlouvě nebo plynou z obchodních zvyklostí.

Individuální vyzkoušení je v praxi používaný pojem pro smluvní povinnost zhotovitele, resp. dodavatele bud' dodávky smontovaného výrobku, nebo montáže, popř. montážních prací. Rozumí se jím vyzkoušení stroje, zařízení nebo technického systému v rozsahu nutném pro prověření jeho úplnosti a jeho funkcí a současně ověření řádného 
provedení montáže, popř. jen ověření řádného provedení montáže (jedná-li se jen o montáže nebo montážní práce).

Komplexním vyzkoušením jsou zkoušky díla, které zásadně tvoří soubor strojů a zařízení. Dodavatel - zhotovitel - jím prokazuje, že dílo je kvalitní a že je schopno zkušebního provozu (pokud je sjednán). Pojem komplexní vyzkoušení určuje, že se komplexně a souběžně zkouší všechny části předmětu plnění.

Zkušební provoz navazuje na komplexní vyzkoušení (doporučujeme přesně sjednat, kdo ho bude provádět, bez výslovného sjednání bychom při interpretaci podle ostatních ustanovení smlouvy mohli docházet $\mathrm{k}$ různým závěrům; obecně přitom je tendence vývoje od zajišt'ování zkušebního provozu objednatelem k povinnosti zhotovitele) a ověřuje, zda zařizení bude za předpokládaných provozních podmínek schopno provozu v rozsahu stanoveném pro zkušební provoz v dokumentaci.

Zkušební provoz je počáteční fáze užívání (provozu) stavby. Během zkušebního provozu se obvykle realizuje náběhová křivka, tj. trajektorie (dráha), po níž se postupně naplňují cíle projektu. Spojuje komplexní vyzkoušení s garančními zkouškami nebo jiným způsobem prokázání a zhodnocení splnění cílů projektu. Alespoň ve svém závěru probíhá již v provozních podmínkách. Navazující garanční zkoušky prokazují, zda zařízení dosahuje ve smlouvě výslovně sjednaných hodnot a ukazatelů.

Zda bude provedeno individuální vyzkoušení, komplexní vyzkoušení, zkušební provoz a garanční zkoušky, popř. zda budou provedeny jen některé či všechny tyto zkoušky postupně, je věcí smluvního ujednání a vyplývá to z charakteru díla. Jestliže podle smlouvy má být řádné provedení díla prokázáno provedením zkoušek, považuje se provedení díla za dokončené až poté, co byly tyto zkoušky úspěšně provedeny.

\section{Základní ustanovení}

\subsection{Podstatné náležitosti smlouvy}

Základní ustanovení smlouvy určuje, že zhotovitel se zavazuje provést na svůj náklad a nebezpečí pro objednatele dílo a objednatel se zavazuje dílo převzít a zaplatit cenu.

Oproti znění Základního ustanovení v obchodním zákoníku je tedy text obohacen o provedení na náklad a nebezpečí zhotovitele, což byl text určený v obchodním zákoníku až v ustanovení § 537, které na základní ustanovení navazovalo. Text Základního ustanovení byl pak obohacen i o zařazení povinnosti převzít dílo, která byla rovněž v obchodním zákoníku v $§ 537$.

Písemná forma smlouvy není předepsaná. Lze ji však jen doporučit, zejména ve výstavbě. Judikatura k tomu určuje, že smlouvu lze uzavřít zčásti písemně a zčásti ústně.

Na platnost smlouvy přitom nemá vliv, že některé práce byly již před uzavřením smlouvy provedeny.

Jinak než dříve je v Základním ustanovení upravena cena. Určuje se, že cena díla je sjednána dostatečně určitě, je-li dohodnut alespoň způsob jejího určení, anebo je-li určena alespoň odhadem. Mají-li strany vůli uzavřít smlouvu bez určení ceny díla, platí za ujednanou cena placená za totéž nebo srovnatelné dílo v době uzavření smlouvy a za obdobných smluvních podmínek. Připomínáme, že uzavírání smlouvy vůlí stran 
bez určení ceny díla nebo odhadem nemůžeme doporučit zejména u rozsáhlé atypické průmyslové výstavby.

Podle judikatury, není-li ve smlouvě dohodnuto jinak, je součástí ceny i daň z přidané hodnoty.

V obchod. zák. bylo určení díla vymezeno v Základním ustanovení v § 536, ve vztahu k Základnímu ustanovení kupní smlouvy $§ 409$ a ustanovení $§ 410$.

V občan. zák. se této otázce věnuje $§ 2587$ a určuje, že dílem se rozumí zhotovení určité věci, nespadá-li pod kupní smlouvu, a dále údržba, oprava nebo úprava věci nebo činnost s jiným výsledkem. Dílem se rozumí vždy zhotovení, údržba nebo úprava stavby nebo její části.

Podle současné právní úpravy nemusí být dnes dílo hmotně zachyceno, umožňuje to širší realizaci tohoto smluvního typu ( napřr. činnost dálkového prredávání dat).

Základní ustanovení neuvádí výslovně, že se smlouva o dílo použije, bude-li předmětem plnění montáž. Pokud však bude podstatná část plnění tvořena právě montáží, pak půjde o smlouvu o dílo, montáž je totiž také činností.

\subsection{Další náležitosti smlouvy}

Při uzavírání smlouvy by podle našeho názoru měli zejména objednatelé (podobně jako u kupní smlouvy kupující) zvážit zařazení (a jeho zařazení doporučujeme) článku „Význam a účel smlouvy“. Obsah tohoto článku není totiž jen proklamací, ale mohou s ním být spojeny závažné právní důsledky ve vztahu k právní úpravě jiných ustanovení (při jejich výkladu).

Ve smlouvě o dílo ve výstavbě by neměly chybět ani základní údaje o stavbě. Domníváme se, že je vhodné uvádět prohlášení objednatele (stavebníka), že stavba je rádně povolena (př́íp. sankce, resp. zastavení nepovolené stavby totiž nepostihnou jen objednatele, ale připraví řadu problémů i zhotoviteli). Je vhodné sjednat, kdy předá (sdělí, že bylo vydáno) objednatel zhotoviteli stavební povolení (pokud nebylo vydáno již před uzavíráním smlouvy). Předáno by mělo být nejpozději při předání a převzetí staveniště.

Neopatřil-li objednatel včas stavební povolení, neposkytl tím potřebné spolupůsobení, aby zhotovitel mohl splnit svůj závazek.

Může však být též dohodnuto, že stavební povolení opatř́ zhotovitel.

Ve smlouvě můžeme zejména také doporučit uvedení názvu a místa stavby a její charakteristiky (např. že se jedná o stavbu trvalou, dočasnou apod.). Pokud by neměly úplnou vypovídací schopnost údaje o významu a účelu stavby, lze ve smlouvě uvést $\mathrm{i}$ článek o důležitosti stavby

Kromě přesné identifikace smluvních stran lze - jde-li o výstavbu - doporučit uvést ve smlouvě:

- Další účastníky výstavby.

- Údaje o investorovi (příp. údaje o budoucím uživateli).

- Alespoň základní řešení dodavatelského systému (tj. které subjekty a jakým způsobem dodávají investorovi) a zakotvení kontrahovaného plnění v něm, včetně určení funkcí generálního dodavatele (zhotovitele) technologické části stavby a generálního dodavatele stavební části stavby, je-li zvolen systém s generálními dodavateli. 
- Kromě přesného označení subjektů sjednávané smlouvy (vč. identifikačního čísla), tj. zhotovitele a objednatele, lze uvést - a je to i velmi praktické - jejich statutární zástupce a osoby (funkcionáře, zaměstnance), které jsou oprávněny ke sjednávání možných smluvních dodatků.

- Pro snadnější plnění povinností vyplývajících z daňových předpisů (zejména ze zákona o dani z přidané hodnoty) se uvádí DIČ (tzv. daňové identifikační číslo).

- Pokud se zasílá zboží, z něhož je dílo vytvořeno, před zahájením prací např. do skladu (skladů) objednatele, neměly by ve smlouvě chybět ani přepravní dispozice, tj. adresa př́ijemce, dohodnutý způsob dopravy a místo určení (je možno též dohodnout i způsob balení, event. jaké zařízení je určeno pro kryté temperované sklady). Zařízení dodávané v obalech i volně je vhodné signovat (označovat dohodnutým kódem), aby bylo zřejmé, pro který objekt či provozní soubor je určeno.

- Vhodné je též sjednat, kdo bude působit jako vedoucí prací (stavbyvedoucí) zhotovitele a kdo bude vykonávat funkci technického dozoru (technického dozorce) investora, koncipovat ujednání o tom, kdo je na dané stavbě oprávněn k zápisům a potvrzování stavebního (montážního) deníku a ke kontrole provedených prací.

- U složitějších staveb mohou být ve smlouvě uvedeny i další osoby, např. zástupci pro věci technické ( $\mathrm{k}$ řešení technických otázek, př́íp. k předkládání technických podkladů pro návrhy dodatků smluv vyplývajících z navrhovaných technických změn), vedoucí „najížděcí skupiny“ (pro řízení jednotlivých druhů zkoušek), koordinátor (pověřený koordinací prací subdodavatelů, event. i jiných dodavatelů dodávajících prímo investorovi), osoby odpovídající za bezpečnost práce na stavbě apod. Tito funkcionáři však nejsou obecně oprávněni sjednávat změny smluv (techničtí zástupci mohou však např. být oprávněni dohodnout drobné změny projektu a v projektu je shodně vyznačit; např. může jít o změnu v údaji kóty stanovící vzdálenost jednotlivých strojů od sebe).

- U rozsáhlejších staveb může být též sjednáno, kdo je jménem smluvních stran oprávněn provést odevzdání a př̀evzetí díla, př́íp. kdo je tzv. odpovědným geodetem zhotovitele a objednatele.

- Ve smlouvách bude pak zpravidla uvedena i osoba vykonávající tzv. autorský dozor projektanta (nebude tam naopak zejména při subdodávce na nižším dodavatelském stupni).

\subsection{Ke smluvním podmínkám FIDIC}

Obsah smlouvy může být obecně určen odkazem na obchodní zvyklosti, obchodní podmínky a vykládací pravidla. Využívány jsou i smluvní podmínky FIDIC. Kontraktace podle FIDIC se rozšiřuje nejen v zahraničí, ale i v tuzemsku.

Soubor základních vzorových smluvních podmínek tvoří v dokumentech FIDIC:

Conditions of Contract for Construction / Smluvní podmínky pro výstavbu pozemních a inženýrských staveb projektovaných objednatelem (zkratka CONS, tzv. Red Book), které jsou podmínkami s vyrovnanou alokací rizik a jejichž použití se předpokládá u projektů, u nichž rizika spojená s projektovou dokumentací ponese 
větší měrou objednatel. CONS jsou smluvními podmínkami pro projekty Generálního dodavatelství (Design-Bid-Build) s použitím specifikací a výkresů objednatele pro zadání a realizaci zakázky a měřením skutečně provedených prací správcem stavby při použití paušálních položkových cen.

Conditions of Contract for Plant and Design-Build / Smluvní podmínky pro dodávku technologických zařízení a projektování a výstavbu elektro- a strojně-technologického díla a pozemních a inženýrských staveb projektovaných zhotovitelem (zkratka P\&DB, tzv. Yellow Book), které jsou podmínkami s vyrovnanou alokací rizik a jejichž použití se předpokládá u Design-Build projektů, u kterých rizika spojená s projektovou dokumentací ponese větší měrou zhotovitel. Na rozdíl od CONS podmínky P\&DB již nepoužívají specifikace a výkresy objednatele pro zadání a realizaci zakázky, pracují s tzv. požadavky objednatele, které definují především účel, funkci, rozsah, standard, výkon a jiná projekční a technická kritéria díla podle představ objednatele. Na základě požadavků objednatele vytváŕí zhotovitel svůj návrh, který se stává součástí smlouvy. Ač je celková cena koncipovaná jako paušální a na rozdíl od CONS se neprovádí měření skutečně provedených prací, může dojít $\mathrm{k}$ její úpravě prostřednictvím změn díla (variací) a v důsledku uplatnění nároků na dodatečné platby a čas. I u tohoto vzoru se využívá správce stavby.

Conditions of Contract for EPC/Turnkey Projects / Smluvní podmínky pro projekty EPC/ „na klíč“ (zkratka EPC nebo EPCT - Engineer, Procure and Construct, tzv. Silver Book), které jsou typické pro projekty Design-Build s přesunutím větší míry rizik (hlavně rizik souvisejících s projektovou dokumentací, odpovědností za kontrolu zadání zakázky a kontrolu fyzických podmínek staveniště) na zhotovitele a jsou doporučovány v prrípadě dodávky investičních celků (napřs. elektrárny), kdy se požaduje větší spolehlivost zajištění celkové ceny a doby výstavby. Pro EPC též platí, že cena je koncipovaná jako paušální, neprovádí se měření skutečně provedených prací, ale může dojít ( $v$ omezeném rozsahu) $\mathrm{k}$ její úpravě prostřednictvím změn díla (variací) a v důsledku uplatnění nároků na dodatečné platby a čas. Tento vzor již nevyužívá správce stavby, ale zástupce objednatele.

Pro odlišení podmínek P\&DB a EPC uvádí FIDIC př́ípady, kdy se doporučuje používat podmínky P\&DB. Jde o situace, kdy: uchazeči o zakázku nemají dostatek času a informací pro kontrolu a zpracování požadavků objednatele v zadávací dokumentaci, některé části výstavby nebo celá realizace stavby jsou v podzemí nebo v těžko prozkoumatelných podmínkách, objednatel chce ve větší míře dozorovat provádění prací nebo schvalovat projektovou dokumentaci zhotovitele, předpokládá se pravidelná kontrola fakturace objednatelem.

O tom, které podmínky se v daném projektu použijí, rozhodne zásadně ta osoba, která ho financuje.

Pro dodávku stavebních prací se dnes nejčastěji používají tři základní vzory smluvních podmínek. Mezi obchodní podmínky smluv na stavební práce a dodávky patří i Short Form of Contract (tzv. Green Book), které jsou smluvními podmínkami určenými pro projekty s malou předpokládanou hodnotou. Je třeba se zmínit také o vzorových smluvních podmínkách DBO (Design, Build and Operate Projects), které vyšly v roce 2008 a jsou variantou podmínek pro projekty, kde se předpokládá též provozování díla zhotovitelem. Dále je vhodné upozornit na vzorový dokument podzhotovitelské 
smlouvy (Conditions of Subcontract for Construction; tzv. Construction Subcontract), jejž FIDIC vydala pro použití v kombinaci s CONS. ${ }^{2}$

\section{Práva a povinnosti stran}

\subsection{Vázanost díla na konkrétní osoby}

Ustanovení $§ 2588$ odst. 1 upravuje případy, kdy dílo nemůže provést nikdo jiný než konkrétní zhotovitel, provedení díla je totiž závislé na jeho zvláštních osobních schopnostech. Tyto schopnosti může mít např. i umělecký kovář nebo kovotepec, který se zavázal vytvořit konkrétní originální dílo. V tomto případě zaniká závazek ztrátou jeho způsobilosti (např. úrazem nebo nemocí) nebo jeho smrtí. To však neplatí, může-li dílo provést ten, kdo činnost zhotovitele převzal jako jeho právní nástupce.

Podle $\S 2588$ odst. 2 smrt objednatele sama o sobě závazek neruší, ledaže by se právě tím stalo splnění závazku nemožným nebo zbytečným.

Dílo nemusí být vázáno na osobní vlastnosti zhotovitele - nebo to není vzhledem $\mathrm{k}$ povaze díla zapotřebí (např. u údržby nápojových automatů). $\mathrm{V}$ takových př́padech nemusí zhotovitel provést dílo osobně a může je nechat provést subdodavatelem. Nejde-li však o uvedené případy, pak platí, že zhotovitel provede dílo osobně nebo pod svým osobním vedením.

Není-li dohodnuto jinak, obstará zhotovitel vše, co je k plnění potřeba.

Není-li ujednána doba plnění, plní se bezodkladně v době přiměřené. Doba plnění je u smlouvy o dílo stanovena ve prospěch zhotovitele. To znamená, že zhotovitel, pokud to smluvní ujednání nevyloučí, by mohl plnit dříve než ve sjednané době plnění.

\subsection{Doba plnění}

Doba plnění nebude mnohdy sjednávána jen jedna - celková, ale bude začasté sjednávána doba pro dílčí plnění a protiplnění. Konkrétní smlouva by měla tyto otázky upravit určitým způsobem.

Podle dohodnutého rozsahu plnění může být u dodávek pro výstavbu sjednáno, jaké předá objednatel zhotoviteli podklady, pokud bude projekty zpracovávat zhotovitel, je-li to dohodnuto, může zhotovitel zajistit i vydání stavebního povolení. Může však být také sjednáno, že př́slušné projekty a stavební povolení zajistí a předá zhotoviteli objednatel.

Bude-li však jednotlivé stupně (druhy) dokumentace dodávat zhotovitel zajišt'ující i hmotné dodávky, lze dohodnout při možnosti dílčího plnění, jaké dokumentace předá objednateli a v jaké době. Jednotlivé druhy dokumentace přitom mohou mít dílčí doby plnění, např. i pro jednotlivé stavební objekty a provozní soubory.

Vhodné je též dohodnout, v jakém místě dojde ke splnění jednotlivých projektových prací a jaká jednání mezi smluvními stranami budou před tím provedena.

Dohodnuta by měla být také doba "předání staveniště“ objednatelem pro zhotovitele

2 Bliže viz publikace L. Klee uvedené v seznamu literatury. 
(tj. předání staveniště ve stavu umožňujícím provádění stavebních prací), která zejména u rozsáhlejších staveb může být též plněna ve sjednaných dílčích dobách postupně.

Rovněž je třeba dohodnout předání "stavební připravenosti", jíž se rozumí již pokročilý stav stavebních prací, který umožní zahájení a plynulé provádění dodávek a montážních prací dodavatelem technologické části stavby. Sjednává se i tzv. "montážní připravenost", což je velmi pokročilý stav montážních prací spadajících do technologické části stavby, který umožní práce stavebních dodavatelů pro úplné dokončení stavebních prací (např. potěry podlah, obklady, malby a další dokončovací stavební práce).

Z jednotlivých protiplnění (plnění objednatele vůči zhotoviteli) může být sjednána zejména doba předání vytýčeného staveniště, určení mezideponií, deponií a skládek, určení zemníků, vytýčení a stabilizace základních směrových a výškových bodů stavby, užívání př́ijezdové cesty, umístění (přemístění) dopravních značek, předání připojovacích míst zdrojů energie, vody apod. Pro plnění zhotovitele i objednatele může být zpracován časový harmonogram činností (včetně uvedení doby dopravy rozhodujících dodávek na stavbu), který bud' celý nebo jen některé jeho části, popřr. sumář rozhodujících činností, může tvořit i součást smlouvy.

Ustanovení § 2591 určuje, že je-li k provedení díla nutná součinnost objednatele, určí mu zhotovitel přiměřenou lhůtu k jejímu poskytnutí. Uplyne-li lhůta marně, má zhotovitel právo podle své volby si bud' zajistit náhradní plnění na účet objednatele, anebo, upozornil-li na to objednatele, odstoupit od smlouvy.

Toto ustanovení se vztahuje zejména (ale nejen) na hmoty, které se objednatel zavázal zhotoviteli zajistit (může se však týkat i některé dokumentace apod.).

Pokud věci, k jejichž opatření se objednatel zavázal, objednatel neopatří včas, je stanoveno, že mu pro to zhotovitel může poskytnout přiměřenou lhůtu a po jejím marném uplynutí může sám po předchozím upozornění opatřit věci na účet objednatele. Objednatel je pak povinen uhradit jejich cenu a účelné náklady s tím spojené bez zbytečného odkladu poté, kdy jej o to zhotovitel požádá. Věci, které jsou potřebné k provedení díla a k jejichž opatření není podle smlouvy zavázán objednatel, je povinen opatřit zhotovitel. ${ }^{3}$

Navazující ustanovení § 2592 ( i ustanovení § 2593) odpovídá dosavadní úpravě obchod. zák. Upravuje, že zhotovitel postupuje při provádění díla samostatně. Opak platí a je pak vázán pokyny objednatele jen tehdy, bylo-li to ujednáno a plyne-li to ze zvyklostí.

Objednatel má právo kontrolovat již provádění díla. Na stavbách či při strojně-technologických dodávkách plní tuto funkci tzv. technický dozor (technický dozorce). Pokud zjistí, že zhotovitel porušuje svoji povinnost, může požadovat nápravu a provedení díla řádným způsobem (např. i provedením př́íslušného zápisu ve stavebním či montážním deníku). Pokud zhotovitel porušuje svoje povinnosti a nezajistí nápravu ani v přiměřené době a vedl-li postup zhotovitele nepochybně k podstatnému porušení smlouvy, může objednatel od smlouvy odstoupit.

3 Jde o tradiční stabilní právní úpravu - viz např. MAREK, K. Smluvní obchodní právo. Kontrakty. 4.vyd. Brno : MU, 2008; uvedeno v seznamu literatury. 


\section{Předmět díla, vlastnické právo}

\subsection{Opatření věcí ke zhotovení díla, upozorňovací povinnost}

Další ustanovení § 2594 má v zásadě stejné řešení jako pro tuto otázku použil obchod. zák. Je zde určena bezodkladná upozorňovací povinnost zhotovitele pro př́pad, že je nevhodná povaha věcí nebo př́kazu, které objednatel zhotoviteli dal. To platí při vynaložení potřebné péče. Neznamená to, že by musel zhotovitel napřr. provádět znova všechny vlastnosti osvědčující atesty, nemůže však přijímat „vstupy“ od objednatele, aniž by jim odpovídající potřebnou péči věnoval.

Podle judikatury je zhotovitel stavby mj. povinen při zhotovování díla při vynaložení minimální odborné péče rozpoznat v průběhu výstavby podstatnou vadu objednatelem předané dokumentace a na tuto vadu objednatele upozornit.

Tvoří-li nevhodná věc nebo pokyn překážku v řádném provádění díla, zhotovitel provádění díla přeruší až do výměny díla či změny př́ikazu. Lhůta pro dokončení díla se prodlužuje o dobu přerušení a zhotovitel má právo na úhradu nákladů s tím spojených po určenou dobu. Pokud by na předané věci či př́íkazu objednatel trval, může zhotovitel žádat, aby mu objednatel toto potvrdil písemně. Pokud zhotovitel postupuje v souladu s touto úpravou $\S 2594$, nemá objednatel právo na vady díla vzniklé nevhodností věcí nebo prŕḱkazů.

Podle $§ 2595$ koncipována ještě možnost zhotovitele od smlouvy odstoupit a to tehdy, trvá-li objednatel na provedení díla podle zřejmě nevhodného př́kazu nebo s použitím zřejmě nevhodné věci i po upozornění zhotovitele.

Opatří-li zhotovitel věc zpracovanou při provádění díla, má stran této věci, pokud se stala součástí díla, postavení prodávajícího. Má se za to, že kupní cena věci je zahrnuta $\mathrm{v}$ ceně díla.

Věci, které má objednatel podle smlouvy opatřit k provedení díla, je povinen předat zhotoviteli v době určené ve smlouvě, jinak bez zbytečného odkladu po uzavření smlouvy. $\mathrm{V}$ pochybnostech se má za to, že o cenu těchto věcí se nesnižuje cena za provedení díla.

Pokud věci, k jejichž opatření se objednatel zavázal, objednatel neopatří včas, je stanoveno, že mu pro to zhotovitel může poskytnout přiměřenou lhůtu a po jejím marném uplynutí může sám po předchozím upozornění opatřit věci na účet objednatele. Objednatel je pak povinen uhradit jejich cenu a účelné náklady s tím spojené bez zbytečného odkladu poté, kdy jej o to zhotovitel požádá. Věci, které jsou potřebné k provedení díla a k jejichž opatření není podle smlouvy zavázán objednatel, je povinen opatrit zhotovitel.

Smluvní strany si tedy mohou dohodnout, kdo opatří věci ke zhotovení díla. Pokud tak smluvní strany učiní, platí smluvní ujednání. Jestliže smlouva záležitost opatření věcí neřeší, pak platí, že věci opatří zhotovitel.

Bylo-li dohodnuto, že věci ke zhotovení díla opatří objednatel, nese tento nebezpečí škody na nich po dobu, po kterou je jejich vlastníkem.

Pokud se bude jednat o věc převzatou od objednatele (např. do opatrování za účelem její opravy nebo úpravy nebo za účelem jejího zpracování při provádění díla), odpovídá zhotovitel jako skladovatel. 
Po dokončení díla nebo po zániku závazku dílo provést je zhotovitel povinen bez zbytečného odkladu vrátit objednateli věci od něho převzaté, jež nebyly zpracovány při provádění díla.

\subsection{Vlastnické právo}

Je-li předmětem díla věc určená jednotlivě, nabývá k ní vlastnické právo objednatel. To neplatí v prŕípadě, že zhotovitel zpracoval věc objednatele na jiném místě než u objednatele či na jeho pozemku nebo na pozemku, který objednatel opatřil, nebo že je hodnota díla stejná nebo vyšší než hodnota objednatelovy zpracované věci, tehdy nabývá vlastnické právo zhotovitel. Výslovně to upravuje $\S 2599$ odst. 1 a zhotovení věci podle druhu naopak určuje vlastnictví zhotovitele $\S 2599$ odst. 2. To koresponduje $\mathrm{s}$ dřívější úpravou obchodního zákoníku.

Navazující ustanovení upravují situace zmaření díla. Pokud zhotovitel nabude zpracováním vlastnické právo k věci a zmaří-li se dílo z důvodu, za nějž zhotovitel neodpovídá, nemá objednatel právo na náhradu za věc, kterou zhotoviteli předal ke zpracování. (Právo z bezdůvodného obohacení tím není dotčeno.) Jestliže však k tomu za stejné situace dojde $\mathrm{z}$ důvodu, za nějž zhotovitel odpovídá, poskytne objednateli náhradu za jeho zpracovanou věc, anebo mu vrátí věc téhož druhu.

Určení toho, kdo nese nebezpečí škody na věci a kdo k ní má vlastnické právo, má pochopitelně značný význam. To lze dokumentovat např́klad u zhotovování díla ve výstavbě. Bude-li ve smlouvě dohodnuto, že vlastníkem je zhotovitel (pak lze ovšem doporučit zhotoviteli pojištění věci a s pojistným uvažovat při sjednávání ceny) a objednatel naprríklad naplnil podmínky zahájení rrízení o úpadku, nebude dílo zahrnuto do podstaty. Důsledkem této situace je ovšem právě ta skutečnost, že zhotovitel nese nebezpečí škody na zhotovované věci (není-li sjednáno jinak).

Naopak, bude-li vlastníkem díla objednatel, potom by se dílo do podstaty mělo zahrnout a pohledávku zhotovitele na zaplacení díla uplatnit při soupisu pohledávek všech věřitelů. Tato pohledávka tedy podle konkrétní situace může být př́padně uspokojena i v nepatrném rozsahu, event. vůbec. Zhotovitel ovšem nenese nebezpečí škody na věci. Nic však nebrání jedné z možných podob dohody, že k dodávkám nese nebezpečí rizik nahodilého poškození objednatel, ale až do úplného zaplacení díla je vlastníkem zhotovitel.

Je tedy možné, že vlastníkem bude jedna smluvní strana a nebezpečí nahodilého poškození ponese strana druhá. Lze též smluvně sjednat určitým způsobem vlastnictví a nositelství nebezpečí ze škod pro pozemky, dosavadní stavby a porost předané zhotoviteli k užívání či péči (v průběhu výstavby) a jiným způsobem pro zhotovované dílo samé.

Konkrétní smluvní úprava musí vycházet z konkrétních podmínek týkajících se smluvních stran a charakteru díla. Zejména je třeba vzít do úvahy způsob a termíny placení, která strana byla příp. nucena vzít si úvěr, zda je dílo předmětem zástavního práva, zda se stává součástí jiného díla apod.

Nemělo by být opomenuto též ujednání o včasném zajištění proti škodám a o pojištění díla v době rozestavěnosti. Smluvně je vhodné řešit i otázky spojené s př́ípadným zánikem závazků provést dílo. 
Při řešení otázek vlastnických vztahů v praxi se setkáváme i s tím, že pro vztahy mezi objednatelem a zhotovitelem na jedné straně a vztahy mezi zhotovitelem a jeho subdodavatelem na straně druhé nejsou volena kompatibilní řešení. Pro tentýž předmět plnění je v jedné smlouvě sjednáno (event. vyplývá ze zákona) vlastnické právo objednatele a v subdodavatelské smlouvě vlastnické právo subdodavatele. Takovým řešením je třeba se vyvarovat a sjednat v celém dodavatelském systému shodný vlastnický režim.

\subsection{Zmaření díla}

Navazující ustanovení $§ 2600$ až 2603 řeší další otázky zmaření díla. Rozlišují přitom, kdo má vlastnické právo k věci, a zda tento subjekt za zmaření odpovídá. Rozlišují se tak čtyři řešení.

Podle $\S 2600$ nemá objednatel právo na náhradu za věc, kterou zhotovitel předal ke zpracování, pokud zhotovitel nabyl zpracováním vlastnictví k věci a pokud se dílo zmaří z důvodů, za které zhotovitel neodpovídá. Nemusí se přitom jednat jen o př́pady, ve kterých odpovídá objednatel, může jít i o př́ípady další.

Oproti právní úpravě v ustanovení § 2600 se v $§ 2601$ jedná o situace, kdy je dílo zmařeno $\mathrm{z}$ důvodů, za něž zhotovitel odpovídá. Tehdy musí zhotovitel poskytnout objednateli peněžitou náhradu za jeho zpracovanou věc, anebo mu poskytne věc téhož druhu.

Ustanovení § 2602 a 2603 řeší situace, ve kterých je vlastníkem objednatel. Pokud zpracováním nabyl vlastnické právo objednatel a zmaří-li se dílo z důvodu, za který zhotovitel odpovídá, může objednatel požadovat bud' vydání věci vzniklé zpracováním, anebo tuto věc odmítnout a požadovat náhradu svých věcí použitých ke zpracování. Vydá-li zhotovitel objednateli věc vzniklou zpracováním, není tím dotčeno jeho právo z bezdůvodného obohacení. Jestliže však objednatel věc vzniklou zpracováním odmítne, má vůči zhotoviteli právo na peněžitou náhradu za zpracovanou věc nebo na vrácení věci téhož druhu.

Jestliže ve stejné vlastnické situaci došlo ke zmaření z důvodů, za něž zhotovitel neodpovídá, může objednatel požadovat jen vydání věci vzniklé zpracováním, nahradí však zhotoviteli cenu jeho věci použité ke zpracování. Shodně s ustanovením $§ 2600$ jde o př́ípady, kdy za zmaření díla neodpovídá zhotovitel, jde tedy bud' o př́ípady, ve kterých odpovídá objednatel, ale nejen o ně, jde i o situace další.

\section{Provedení díla}

\subsection{Dokončení díla}

Podle $\S 2604$ je dílo provedeno, je-li dokončeno a předáno. Musí být splněny obě tyto podmínky. Přitom je dílo dokončeno, je-li předvedena jeho způsobilost sloužit svému účelu.

Nepředá-li zhotovitel dílo objednateli způsobem ve smlouvě sjednaným, nenastane splatnost ceny díla a objednatel není v prodlení s úhradou ceny díla.

Objednatel převezme dokončené dílo s výhradami, nebo bez výhrad. Objednatel by měl řádně provést prohlídku díla. 
Vzhledem k tomu, že je kritériem dokončení díla způsobilost sloužit svému účelu, je vhodné uvést účel díla prrímo ve smlouvě. Objednatel přitom dílo převezme bud' $\mathrm{s}$ výhradami nebo bez výhrad. Měl by se přitom s dílem řádně seznámit. Musí zejména uplatnit s výhradou (s výhradami) zjevné vady. Pokud objednatel převezme dílo bez výhrad, nepřizná mu soud právo za zjevné vady díla, a to jestliže zhotovitel namítne, že právo nebylo uplatněno včas.

Dohodou se určuje, kdy bude dokončeno provedení díla včetně smluvených podmínek druhu zkoušek a podmínek sepsání zápisu o převzetí (včetně jeho obsahu). Může být pochopitelně dohodnuto plnění po částech, např. po stavebních objektech a provozních souborech, současně lze sjednat i odpovídající bonifikace a sankce (smluvní pokuty) ve vztahu k těmto dobám.

Zhotovování díla zejména ve výstavbě bude činností značně složitou a včasné a řádné plnění bude mnohdy záviset i na spolupůsobení (vhodně sjednaném) ostatních osob, zejména objednatele (již zmíněné předání staveniště, případně předání dokumentace apod.).

V řadě případů nemůže přitom zhotovitel zabezpečit celé zhotovení díla vlastními zaměstnanci, ale bude kontrahovat subdodávky (zejména elektroinstalace, izolace, vzduchotechniku apod.). Tento postup mu zákon umožňuje. Zhotovitel díla totiž může pověřit jeho provedením jinou osobu, jestliže ze smlouvy nebo z povahy díla nevyplývá nic jiného. Při provádění díla jinou osobou má zhotovitel odpovědnost, jako by dílo prováděl sám.

Zhotovitel bude přitom se subdodavateli uzavírat rovněž smlouvy o dílo, ale i smlouvy kupní a jiné, včetně smluv inominátních.

Pro tyto případy lze zhotoviteli doporučit „hru na dopravního strážníka“, tj. sjednat podmínky subdodávek (mimo jiné záruční) ve shodě s podmínkami kontraktu $\mathrm{s}$ objednatelem.

Pro případ, že by objednateli poskytl „lepší plnění“, tj. výhodnější podmínky, než má smluvně zajištěny se subdodavateli, měl by se rizika z toho plynoucí (např. rozdíly v zárukách) snažit řešit při sjednání ceny. Realizace tohoto doporučení však není jednoduchá, nebot' mezi sjednáváním smlouvy mezi investorem a zhotovitelem a zhotovitelem a subdodavateli bývá relativně dlouhá lhůta.

Složitost při plnění smlouvy o dílo, například ve výstavbě, vyplývá mimo jiné z delší doby plnění, než je tomu u jiných smluv, vysokých finančních objemů a zpravidla většího počtu osob na výstavbě zúčastněných. Mưže ovšem vyplývat i z toho, že věci potřebné ke zhotovení díla, resp. část věcí, opatří objednatel.

Půjde-li v daném př́padě o zhotovení projektu, popř. i dodávky části stavební a technologické, dohodne se i výkon a rozsah autorského (nebo občasného autorského) dozoru.

Pokud se neprovádí zhotovení celé technologické a stavební části stavby, měla by smlouva určovat, které objekty, stavební práce, provozní soubory a provozní jednotky tvoří předmět plnění. Je vhodné dohodnout i rozsah zařízení staveniště.

Co se týká zpracování jednotlivých „stupňư“ (druhů) projektové dokumentace, je vhodné dohodnout, kdo a v jakých termínech projedná dokumentaci a se kterými veřejnoprávními orgány. Zhotovitel např. může provádět jen taková ve smlouvě určená jednání, která využije pro účely dokončení projektu. 
Pokud smlouva o dílo zpracování projektů zahrnuje, je třeba zpravidla dohodnout i termíny, v jakých zhotovitel a objednatel projednají dokumentaci v průběhu jejího zpracování (např. koncepci řešení; v realizační dokumentaci např. v závěru zpracování). Ve smlouvě má své místo též ujednání o tom, jaké podklady a v jakých lhůtách si smluvní strany předávají v průběhu zpracování projektů.

Případně je možné se dohodnout i na předání specifikace náhradních dílů i na jejich dodávkách a na dodávkách servisních prací, a to pochopitelně nejen pro dobu, kdy po splnění zhotovitel odpovídá za vady, event. pro záruční dobu, ale i pro dobu ,pozáruční““.

V praxi činí obtíže zejména u provádění rekonstrukcí a modernizací staveb provádění změn dohodnutého díla. $V$ průběhu provádění díla se totiž mohou zjištovat (mj. u desítek let starých bytových domů) nové skutečnosti, které nebylo možno zjistit (nebo by to bylo možné jen obtížně a při značném vynaložení nákladů) ani při stavebnětechnických průzkumech či při pasportizaci, které byly prováděny před zpracováním projektové dokumentace.

Právní úprava se složitostí provádění díla počítá a jak je zřejmé ze zákonného textu, umožňuje, za podmínek tohoto ustanovení, tj. lze-li jednotlivé stupně díla odlišit, předání a převzetí po částech.

Ve smlouvě bychom neměli opomenout ani ujednání o zkouškách. Jestliže podle smlouvy má být řádné provedení díla prokázáno provedením dohodnutých zkoušek, považuje se provedení díla za dokončené až poté, co byly tyto zkoušky úspěšně provedeny. K účasti na zkouškách je zhotovitel povinen objednatele včas pozvat. Neúčast objednatele na zkouškách, k jejichž provedení byl včas pozván, nebrání to provedení zkoušek, nevylučuje-li to povaha věci.

Provádění zkoušek bude typické zejména ve výstavbě, ale např. i při vývoji a výzkumu. Pokud budou zkoušky a jejich výstupy stanoveny předpisy nebo závaznými normami normalizační soustavy (ČSN), je třeba tuto skutečnost respektovat (např́klad předepsaná měření a výchozí revizní zprávy). Tam, kde druh zkoušek závazně předepsán není, doporučujeme dohodnout jej ve smlouvě, respektive uvést jej v její př́loze a přesně popsat.

Pro provádění některých zkoušek je vhodné dohodnout ve smlouvě zpracování zvláštní dokumentace (např. pro komplexní vyzkoušení, zkušební provoz a garanční zkoušky), doby zpracování návrhu a jejího odsouhlasení. V návrhu bude i způsob ověřování zkoušek a stanovení, kdy proběhly úspěšně, a obsah zápisu (zápisů o nich).

Výsledek zkoušky se zachytí v zápisu. Jestliže není objednatel př́itomen, potvrdí zápis místo něho hodnověrná, odborně způsobilá a nestranná osoba, která se zkoušek zúčastnila. Občanský zákoník dále upravuje, že nepříčí-li se to povaze závazku, je zhotovitel objednateli povinen zápis předat.

Pokud by byla předmětem díla věc, řídí se podle $\S 2608$ předání věci obdobně ustanoveními o kupní smlouvě. Převzetím nabývá objednatel vlastnické právo k věci a přechází na něho nebezpečí škody na věci, nestalo-li se tak již dřive.

Ustanovení § 2609 určuje, kdy může zhotovitel dílo prodat po vyrozumění objednatele (odst. 1) a kdy bez vyrozumění (odst. 2).

Podle odst. 1 musí být splněny tyto podmínky: prodej musí být uskutečněn vhodným způsobem; objednatel nepřevzal dílo bez zbytečného odkladu poté, co dílo mělo být dokončeno. Bylo-li dílo dokončeno později, pak může být vhodným způsobem 
prodáno bez zbytečného odkladu po vyrozumění o dokončení díla. Nebrání-li tomu povaha věci, stanoví se nejprve náhradní lhůta k převzetí věci, která není kratší než jeden měsíc. Současně zhotovitel objednatele vyrozumí, že jinak bude věc prodána.

Podle odst. 2 § 2609 může zhotovitel prodat věc bez vyrozumění, nehlásí-li se neznámý nebo nesnadno dosažitelný objednatel o dílo po dobu delší šest měsíců. Prodat věc bez vyrozumění lze i tehdy, pokud se objednatel nehlásí o věc po dobu přiměřenou její povaze.

\subsection{Právo na zaplacení ceny}

Právo na zaplacení ceny díla vzniká provedením díla. Je-li dílo přejímáno po částech, vzniká právo na zaplacení ceny za každou část př̀ jejím provedení.

Zhotoviteli a objednateli je umožněno, aby si sjednali placení zálohy. Pokud tak neučinili a jde o dílo bud' se značnými náklady nebo takové dílo, které se provádí po částech, může zhotovitel požadovat během provádění díla přiměřenou část odměny $\mathrm{s}$ přihlédnutím $\mathrm{k}$ vynaloženým nákladům. Lze to realizovat mj. i tak, že se měsíčně sepíší tzv. zjišstovací protokoly či soupisy provedených prací, na základě kterých se část odměny ve smyslu tohoto ustanovení uhradí.

V otázkách placení je možno široce využít smluvní volnosti. Lze dohodnout placení záloh, vystavování dílčích faktur, příp. zda se bude vůbec fakturovat. Pokud by došlo k dohodě o provádění fakturace, je vhodné dohodnout lhůty pro vystavení faktury (faktur), náležitosti faktur, lhůty splatnosti, sankce (smluvní pokuty při nedodržení některého ujednání) a výši úroku pro př́ípad pozdní úhrady.

Pro př́ipad, že by objednatel zmařil provedení díla $\mathrm{z}$ důvodu, za nějž odpovídá, náleží zhotoviteli podle $\S 2613$ cena za dílo snížená o to, co zhotovitel neprovedením díla ušetřil - jde o obdobné řešení, které bylo v obchodním zákoníku.

Dohodnou-li se strany po uzavření smlouvy podle $\S 2614$ na omezení rozsahu díla a neujednají-li důsledky pro výši ceny, zaplatí objednatel cenu upravenou s přihlédnutím $\mathrm{k}$ rozdílu v rozsahu nutné činnosti a v účelných nákladech spojených se změněným prováděním díla.

Ustanovení § 2614 přináší řešení obdobné ustanovení $§ 549$ obchodního zákoníku. Určuje se, že dohodnou-li se strany po uzavření smlouvy na omezení díla (§ 549 počítal nejen s omezením, ale i s rozšířením a změnou díla) a neujednají-li důsledky pro výši ceny, zaplatí objednatel cenu upravenou s přihlédnutím k rozdílu v rozsahu nutné činnosti a v účelných nákladech spojených se změněným provedením díla.

I když se hovoří jen o omezení rozsahu díla, bude podle našeho názoru vhodné volit obdobné řešení i pro dohodnuté rozšsiření nebo změnu díla. I zde se použije stejných kritérií. Je však třeba to sjednat ve smlouvě, když tyto situace zákon neupravuje.

\section{Cena díla}

Cena může být stanovena jako pevná nebo podle rozpočtu (zaručeného-úplného, nezaručného-neúplného, nezávazného) anebo stanovením způsobu určení ceny (např. podle kalkulačního vzorce), tak, že se strany dohodnou, že smlouva vzniká bez dohody o ceně a odhadem. K ceně může být sjednaná cenová i měnová doložka. 
Občan. zák. přitom obecně upravuje i dohodu o zúžení prací (tzv. "méněpráce“ ); pro tento případ určuje postup ke snížení ceny díla. Rozšíření prací ( tzv. „vícepráce“) zákon dnes neupravuje, tuto otázku je však možno řešit smluvně.

\subsection{Pevná cena a způsob stanovení ceny}

Je-li sjednána ,pevná cena“, pak se může stát, že zhotovitel případně nedosáhne (např. když dojde ke zvýšení ceny některých vstupních dodávek nad očekávanou hladinu cen) předpokládaného kladného hospodářského výsledku. Naopak při některých příznivých skutečnostech (např. se podaří kontrahovat kvalitní subdodávku s cenou nižší, než bývá obvyklé) tomu může být naopak. Přitom způsoby stanovení ceny tvoří široký vějír ř řšení (např. odkazy na ceníky, kalkulační vzorce apod.). Pro určení ceny je přitom také možné, aby byly zpracovávány rozpočty. U smlouvy o dílo bývá určována cena podle rozpočtu poměrně často, typické to bude zejména ve výstavbě, ale i ve vývoji a výzkumu (naprríklad ve vývoji nového strojně - technologického zařízení). Na výši ceny nemá vliv, že cena byla určena na základě rozpočtu, jenž je součástí smlouvy nebo byl objednateli sdělen zhotovitelem do uzavrení smlouvy.

Nebyl-li rozpočet označen jako neúplný nebo nezávazný nemůže zhotovitel oprávněně žádat zvýšení ceny díla. To platí jak pro př́ípady, kdy se např. zvýší ceny subdodávek, tak i pro prípady, že bude tř̌eba např̀. u potrubních rozvodů energií třeba širšího plnění (větší metráže).

Při složitých dílech je pravidelně vypracován rozpočet sloužící ke stanovení a odůvodnění výše ceny. Byl-li rozpočet jen pomůckou pro ujednání ceny ve smlouvě pevnou částkou, platí mezi stranami takto ujednaná cena díla a př́ípadné změny rozpočtu (nebo chyby v něm) změnu pevně dohodnuté ceny zásadně neovlivní.

Přece jen však mohou nastat mimořádné okolnosti, odůvodňující zmírnění tvrdosti tohoto pravidla. $Z$ toho důvodu se převzalo ze švýcarského práva řešení situace, kdy provedení díla ztíží a prodraží mimořádná okolnost blížící se svým charakterem vyšší moci. Nedohodnou-li se strany v takovém př́padě o zvýšení ceny, navrhuje se, aby o přiměřeném zvýšení ceny rozhodl na návrh zhotovitele soud, př́padně aby soud měl možnost smlouvu zrušit a rozhodnout o vypořádání stran.

Nové ustanovení $§ 2620$ odst. 2 je úpravou, která dosud v našem právním řádu nebyla zakotvena. Pamatuje na zcela mimořádné nepředvídatelné okolnosti. Za určených podmínek umožňuje, aby soud rozhodl o spravedlivém zvýšení ceny za dílo.

Bylo-li dílo zadáno podle rozpočtu, přejímá se standardní úprava rozlišení rozpočtu na zaručený a nezaručený. Při rozpočtu zaručeném co do závaznosti a úplnosti nelze cenu zvýšit jinak než dohodou stran.

Naproti tomu nezaručený rozpočet umožňuje zhotoviteli jednostranně zvýšit cenu, objeví-li se nutnost vyšších nákladů nebo dalších prací, musí však takovou nutnost bezodkladně oznámit objednateli, jinak právo na zvýšení ceny ztrácí.

\subsection{Rozpočet neúplný a nezávazný}

Jestliže však byla cena určena na základě rozpočtu, daného s výhradou, že se nezaručuje jeho úplnost, může se zhotovitel domáhat př̀měřeného zvýšení ceny, 
objeví-li se při provádění díla potřeba činností do rozpočtu nezahrnutých, pokud tyto činnosti nebyly předvídatelné v době uzavření smlouvy.

Rozpočet s nezaručenou úplností lze při výstavbě použít např́iklad u rekonstrukcí a modernizací, kdy je v rozpočtu na základě výsledků průzkumů (s řádnou odbornou pečlivostí provedených) předaných objednatelem uvažováno s určitým počtem jednotek materiálu včetně prací. Přri realizaci je pak možné po demontáži dosavadního zařízení zjistit zvýšenou potřebu těchto jednotek. Musí však být současně naplněna podmínka, že to nebylo možno předvídat při uzavření smlouvy.

Kromě rozpočtu s nezaručenou úplností zná zákoník i rozpočet nezávazný. Byla-li cena určena na základě rozpočtu, daného s výhradou, může se zhotovitel domáhat, aby byla cena zvýšena o částku, o niž nevyhnutelně převýší náklady účelně vynaložené zhotovitelem původní náklady zahrnuté do rozpočtu.

Označení rozpočtu za nezávazný se zejména bude využívat v období, v němž bude reálné předvídat pohyb cenových hladin. Zhotovitel bude nejen prokazovat, že došlo ke zvýšení cen, ale také bude muset dokázat, že právě tyto vstupy musel použít, nebot' to bylo nevyhnutelné. K označení rozpočtu za nezávazný je ovšem vhodné další podrobnější ustanovení ve smlouvě, např. o tom, od jakých subdodavatelů bude zhotovitel nakupovat a $\mathrm{v}$ jaké době.

Aby nebyla ztížena otázka důkazů a komplikovaného výpočtu (rozpočty totiž obsahují desítky, mnohdy stovky položek), není vyloučeno sjednat nezávaznost rozpočtu jen u položek rozhodujících. Nesouhlasí-li objednatel se zvýšením ceny, určí její zvýšení soud na návrh zhotovitele.

Zhotoviteli však zaniká nárok na určení zvýšení ceny podle ustanovení o rozpočtu s nezaručenou úplností, jestliže neoznámí nutnost př̌kročení rozpočtové částky a výši požadovaného zvýšení ceny bez zbytečného odkladu poté, kdy se ukázala jeho nevyhnutelnost (nikoli tedy kdy k tomu došlo, ale kdy se tak ukázala jeho nevyhnutelnost).

Ustanovení o rozpočtu s nezaručenou úplností a o rozpočtu nezávazném chrání zhotovitele. Obecně by nebylo možno vyloučit, že zvýšení by mohlo být řádově vyšší. Proto obchodní zákoník obsahuje i text, kterým chce prospívat objednateli.

Objednatel může bez zbytečného odkladu odstoupit od smlouvy, požaduje-li zhotovitel podle př́slušných ustanovení zákoníku zvýšení ceny, jež přesahuje o více než $10 \%$ cenu stanovenou na základě rozpočtu. V tomto př́padě je objednatel povinen nahradit zhotoviteli část ceny odpovídající rozsahu částečného provedení díla podle rozpočtu.

\subsection{Cena určená odhadem}

Co se týká ceny určené odhadem, pak zjistí-li zhotovitel po uzavření smlouvy, že cenu určenou odhadem bude třeba podstatně překročit (lze uvažovat o překročení více než $10 \%$ ), oznámí to bez zbytečného odkladu objednateli s odůvodněním nové ceny. Pokud by to neučinil bez zbytečného odkladu poté, co potřebu zvýšení ceny zjistil, anebo zjistit měl a mohl, právo na zaplacení rozdílu v ceně nemá. Jestliže zhotovitel oznámil objednateli zvýšení ceny v souladu s určenými podmínkami, může objednatel od smlouvy odstoupit. $\mathrm{V}$ tomto prrípadě zaplatí zhotoviteli poměrnou část původně určené ceny, má-li z částečného plnění prospěch. 
V prŕípadě nepodstatného zvýšení ceny není nutný předběžný souhlas odběratele, který je povinen cenu navýšenou v tomto rozsahu zaplatit.

O tom, jak bude reagovat na oznámení o podstatném překročení ceny, se musí objednatel rozhodnout bez zbytečného odkladu. Neodstoupí-li totiž objednatel od smlouvy bez zbytečného odkladu po doručení oznámení o vyšší ceně, platí, že se zvýšením ceny souhlasí.

U obsahově složitějších smluv se v praxi smluvně vytváří konstrukce tvorby celkové ceny vč. řešení vzájemných kompenzací, změn díla a cenových doložek rozlišují se přitom tzv. ceny paušální, měřené a nákladové.

Speciální ustanovení § 2625 upravuje, že je-li cena určena s odkazem na skutečný rozsah práce a jeho hodnotu nebo hodnotu použitých věcí a výši dalších nákladů, vyúčtuje zhotovitel na žádost objednatele dosavadní postup prací a dosud vynaložené náklady. Jde o př́pady, kdy nebude sjednána cena podle rozpočtu ani cena pevná, ale půjde zejména o situace, pro které je sjednán „Kalkulační vzorec“.

Kromě úplaty za dílo, tj. určení ceny, zálohy, placení je možno též dohodnout různé způsoby placení: převodem (na příkaz plátce), inkasem (na příkaz příjemce), placením směnkou (směnkami), za použití dokumentárního akreditivu atd.

\section{Vady díla}

Vady díla jsou upraveny v $§ 2615$ až 2619 (vady stavby jsou pak speciálně řešeny ještě v oddílu nazvaném Stavba jako předmět díla v $§ 2629$ až 2630). Je určeno, že dílo má vadu, neodpovídá-li smlouvě, a pro práva z vadného plnění odkazuje na obdobné použití ustanovení o kupní smlouvě. Objednatel však ani podle této úpravy není oprávněn požadovat provedení náhradního díla, jestliže předmět díla vzhledem k jeho povaze nelze vrátit nebo předat zhotoviteli. Posléze uvedené se použije např. pro nosný sloup či komín prováděný kontilitím, který sice není proveden přesně podle dokumentace, avšak má dostatečnou pevnost a výšku.

Zhotovitel odpovídal podle obchodního zákoníku za porušení práva jiné osoby $\mathrm{z}$ průmyslového vlastnictví nebo jiného duševního vlastnictví v důsledku použití předmětu díla, jestliže $\mathrm{k}$ tomuto porušení dojde podle českého právního řádu nebo podle právního řádu státu, kde má být předmět díla využit, a zhotovitel o tom věděl v době uzavření smlouvy. Pro právní vady díla platila přiměřeně příslušná ustanovení obchodního zákoníku o smlouvě kupní.

Podle ustanovení § 2616, dojde-li podle českého právního řádu nebo podle právního řádu státu, kde má být předmět díla využit, $v$ důsledku k použití předmětu díla, $\mathrm{k}$ ohrožení nebo porušení práva třetí osoby z průmyslového vlastnictví, je $\mathrm{z}$ toho zhotovitel objednateli zavázán, pokud o tom zhotovitel v době uzavření smlouvy věděl nebo vědět musel. Na právní vady se obdobně použijí ustanovení o právních vadách předmětu koupě. Tato právní úprava je oproti předchozí úpravě prŕísnější. Určuje, že nejde jen o případy, kdy to zhotovitel v době uzavření smlouvy věděl, ale i pro př́ípady, kdy to vědět musel. Nemusí přitom jít jen o porušení těchto práv, stačí jejich ohrožení.

Ustanovení $§ 2617$ obecně pro dílo určuje, že má-li dílo při předání vadu, zakládá to povinnost zhotovitele z vadného plnění. Přechází-li však nebezpečí škody na 
objednatele až později, rozhoduje doba tohoto přechodu. Po této době má objednatel práva z vadného plnění, způsobil-li vadu porušením své povinnosti.

Soud pak nepřizná objednateli právo z vadného plnění, neoznámí-li - podle $\S$ 2618 - objednatel vady díla bez zbytečného odkladu poté, kdy je zjistil nebo při náležité pozornosti zjistit měl, nejpozději však do dvou let od předání díla, a namítne-li zhotovitel, že právo bylo uplatněno opožděně.

Dal-li však zhotovitel podle $\S 2619$ za jakost díla záruku, použijí se pro záruku obdobně ustanovení o kupní smlouvě.

U vad, na něž se vztahuje záruka, platí místo lhůty dvou let záruční doba. Odpovědnost za vady podle zákonné úpravy není pro objednatele zdaleka tak výhodná (viz formulaci o odpovědnosti při porušení zhotovitelovi povinnosti) jako v př́padě, sjedná-li záruku (mj. musí být dílo po určitou dobu způsobilé sjednanému - jinak obvyklému účelu). Sjednání záruky se tedy jeví v zájmu objednatele.

Záruční doba, je-li sjednána, počíná běžet předáním díla. Pro záruku za jakost díla jinak platí přiměřeně ustanovení o kupní smlouvě.

\section{Další ustanovení a ujednání}

Souborem zvláštních ustanovení se upravují některá specifika děl prováděných jako stavební práce. Typické př́pady jsou zhotovení stavby, její oprava nebo úprava, mohou však přicházet v úvahu i jiné úpravy nemovité věci.

Předně má zhotovitel nést nebezpečí škody na stavbě až do jejího předání (ledaže by ke škodě došlo i jinak). V tom směru se přejímá $§ 651$ dřivějšího občanského zákoníku.

Objednatel má i při stavebních pracích právo kontrolovat její provádění již podle obecné úpravy.

Objednateli je přiznáno také právo požadovat předložení průběžného vyúčtování provedených prací a vynaložených nákladů v těch př́padech, kdy je cena ujednána podle jejich skutečného rozsahu. Ten bude ověřen. Ustanovení o kontrolách díla na určitém stupni jejich provádění a o skrytých překážkách jsou převzata z obchodního zákoníku (§ 552 a 553).

Pokud se jedná o práva z vadného provedení díla - stavby, vymezil dřivější občanský zákoník č. 40/1964 Sb. dobu, do které mohou být uplatněny, třemi léty ( 646 odst. 3), obchodní zákoník pěti lety (§565 odst. 2). NOZ se přiklání řešení obchodního zákoníku, které více odpovídá mezinárodním standardům. Avšak vzhledem k tomu, že u určitých částí stavby nelze pravidelně garantovat pětiletou životnost, navrhuje se po vzoru $\S 646$ odst. 3 dosavadního občanského zákoníku umožnit, aby v určitých případech pro některé části stavby prováděcí předpis tuto dobu zkrátil. Totéž se navrhuje umožnit i pro úmluvu stran; v tom případě však nelze zhoršit postavení objednatele, je-li slabší stranou.

Ustanovení § 2623 výslovně uvádí, že se pro stavby použije ustanovení prvního oddílu právní úpravy smlouvy o dílo. Jedná se o ustanovení § 2586 - 2619. Podle našeho názoru je však pro výstavbu typická i právní úprava druhého oddílu, tj. § 2620 - 2622, která se použije též. 


\subsection{Spolupůsobení}

Pro výstavbu je typické spolupůsobení, tj. plnění jednotlivých povinností, na nichž je závislé včasné plnění partnera (např. při ukládání beztlakých zemních nádrží zajistí objednatel - je-li to dohodnuto - na příslušné místo přívod vody pro jejich těsnostní zkoušku, ve stanovených dobách umožní zhotoviteli na př́slušných místech odběr elektrické energie pro svářečské práce na rozvodu potrubí apod.).

Pokud není prováděna dodávka "na klíč" a objednatel má ve výstavbě jako smluvní partnery více zhotovitelů, musí být přesně prováděno i postupné předávání pracoviště. Může být též dohodnuto dočasné využívání jednotlivých objektů objednatele jako zařízení staveniště.

Otázky zařízení staveniště, tj. otázky budování nových či využití dosavadních objektů a zařízení pro sociální, provozní a výrobní účely zhotovitele (zhotovitelů), je opět vhodné dohodnout ve smlouvě. (Jedná se např. o objekty pro stravování, ubytování pracovníků, kryté i otevřené sklady a mj. př́ípojky inženýrských sítí.)

Dohodnout je př́ípadně třeba i otázky přepravních dispozic a vykládky zásilek. Dá se říci, že úměrně s rozsahem díla může růst i rozsah jednání o spolupůsobení.

U rozsáhlé výstavby je sjednána ve smlouvě řada vzájemných dílčích plnění (protiplnění). Některá mohou mít pro celkový výsledek zásadní význam, jiná mohou mít v daném př́ípadě jen okrajovou povahu (př́ikladem prvých může být nepředání stavební připravenosti, příkladem posléze uvedených jen nedostavení se objednatele k dílčímu zakrývání prací, které se posléze stanou nepř́istupnými).

Při sjednávání otázek spolupůsobení je proto možné dohodnout, které dílčí povinnosti objednatele jsou těmi, na jejichž včasném splnění závisí řádné plnění zhotovitele.

Smluvně je možno volit různá řešení při spolupůsobení objednatele od minimálního rozsahu až po rozsah velmi podstatný. To najde i svoje vyjádření v ceně díla, kdy při minimu spolupůsobení bude cena zřejmě vyšší. Komplexní plnění s minimem jeho spolupůsobení sice objednatele méně zatěžuje, v konkrétních případech se však může stát, že pak zhotovitel např. přesunuje na stavbu mechanismy, které objednatel vlastní a plně nevyužívá, což nemusí být pro obě strany ekonomicky výhodné.

Dohodnuté spolupůsobení a rozsah spolupráce by však měl být vyjádřením smluvní vůle obou stran o racionálním řešení, nikoli výsledkem zneužití faktického silnějšího postavení některé ze smluvních stran. (Rubem racionálního řešení by např. bylo, kdyby zhotovitel nutil objednatele, aby od třetí osoby zakoupil speciální zařízení, které jinak nevyužije, a to proto, aby si jej v době výstavby vypůjčoval, nebo kdyby např. objednatel trval na tom, že si vodu potřebnou pro zkoušky musí zhotovitel zajistit sám, a přitom měl k dispozici dostatečný vodní zdroj).

Pro sjednané spolupůsobení při postupně probíhajících pracích nemusí být doba jejich provádění dohodnuta ve smlouvě (jejich druh však ano), ani uvedena v př́íp. harmonogramu prací, pokud jde o velmi dílčí otázky u rozsáhlé akce, kdy nelze jejich provádění stanovit s denní přesností, a jedná se o spolupůsobení krátkodobé (např̀. př́má přítomnost hasičů z útvaru objednatele při provádění některých prací). U takové dohodnuté kategorie spolupơsobení může být sjednáno, že se vyžádání provede např. zápisem ve stavebním (montážním) deníku a dohodne se, kolik dní předem bude vyžádání provedeno. 
Obecně by však v rámci spolupůsobení mělo být i na stanovení konkrétních lhůt těchto plnění pamatováno prímo ve smlouvě.

Mimo rozsah ujednání ovšem nemohou u spolupůsobení zůstat ani ujednání o jejich úplatě (ujednání o úplatě může vést $\mathrm{k}$ racionálnosti jejich rozsahu) či bezúplatnému poskytnutí (což může mít př́íp. další příznivý vliv na cenu díla).

Objednatel i zhotovitel přitom musí zvažovat, zda se pro př́ípad porušení povinnosti smluvní strany bude vycházet ze zákonné úpravy odpovědnosti za škodu, nebo zda se př́ípadně sjednají smluvní pokuty.

Povinnost k včasnému předání staveniště, event. zařízení staveniště, příp. předání montážního pracoviště, patří mezi rozhodující povinnosti objednatele. Konkrétně při předání staveniště je vhodné definovat, o jaké místo se jedná, jak je vymezeno a jaký je jeho stanovený rozsah. Může být dohodnuto, jak je staveniště vytyčeno s odkazem na př́slušnou dokumentaci.

Začasté bude třeba $\mathrm{v}$ návaznosti na dohodnutý rozsah předmětu plnění sjednat předání podkladu, v němž budou uvedeny všechny rozvodné sítě, kanalizace a další zařízení, event. prohlášení, že takových není.

Jestliže se jedná o stavbu v místech, která vyžadují zvláštní opatření ochrany protipožární, hygienické, ochrany životního prostředí, je potřeba dohodnout mj. označení daných prostorů. Ve smlouvě by se nemělo prípadně zapomenout - podle povahy plnění - i na eventuální spolupůsobení při odvodnění stavby.

Rovněž bude začasté vhodné sjednávat zřízení či užívání cest pro př́íchod a př́ijezd, jakož i zabezpečení osvětlení, zřízení přívodu elektrické energie, vody apod. Ujednávat by se mělo také to, kdo obstará povolení k uživání veřejných ploch a kdo bude hradit př́islušné poplatky. Součástí smlouvy mohou být i ujednání o spolupůsobení při přeložkách podzemních vedení a překopech veřejných komunikací.

Předmětem dohody budou i tzv. vstupy na staveniště (pracoviště). Dohodnuto přitom bude, kteř́ zástupci objednatele jsou oprávněni ke vstupu, a pokud se staveniště nachází ve zvlášt' stř̌eženém prostoru, jak bude zajištěn vstup pro pracovníky zhotovitele.

V úvahu pak může přicházet i spolupůsobení při odstraňování odpadů a nečistot vzniklých zhotovováním díla.

Stranou zájmu účastníků smlouvy nezůstane začasté ani problematika střežení a event. oplocení staveniště. Vhodné je též sjednat spolupůsobení při př́pravě a provádění zkoušek, při převzetí díla a vyklizení staveniště.

Může být dohodnuto i spolupůsobení (napřs. podrobnosti zajištění vstupů) pro případ odstraňování vad díla zhotovitelem po splnění, např. v záruční lhůtě nebo při oznámení vad po splnění.

Může se jednat i o poskytnutí mechanismů, lešení, montážních plošin, pomoc při přepravě a skladování hmot, prííp. provádění dalších činností.

Při sjednávání spolupůsobení ve smlouvách o dílo ve výstavbě lze široce smluvně využít skutečnosti, že právní úprava je stručná a zásadně dispozitivní, smlouvu lze vhodně „tvořit" podle konkrétních podmínek. 


\subsection{Provádění kontrol a vedení deníku}

Kontrola díla může být průběžná. Zejména ve výstavbě však může být praktické sjednat dobu provedení některých kontrol ve smlouvě, zejména u prací, které budou v dalším průběhu zakryty. Pokud by nebyla sjednána specifická ujednání ve smlouvě, nemá obecně vliv př́padné neprovedení kontroly na možnost uplatnit odpovědnost za vady.

Objednatel oprávněn kontrolovat provádění díla. Kromě kontroly uskutečňované průběžně bude přicházet $\mathrm{v}$ úvahu i kontrola předmětu díla na určitém stupni jeho provádění.

Stanoví-li smlouva, že objednatel je oprávněn zkontrolovat předmět díla na určitém stupni jeho provádění, je zhotovitel povinen včas objednatele pozvat k provedení kontroly. Nesplní-li zhotovitel tuto povinnost, je povinen umožnit objednateli provedení dodatečné kontroly a nést náklady s tím spojené.

Nedostaví-li se objednatel ke kontrole, na kterou byl řádně pozván nebo která se měla konat podle dohodnutého časového rozvrhu, může zhotovitel pokračovat v provádění díla. Jestliže však účast na kontrole byla objednateli znemožněna vyšší mocí, může objednatel bez zbytečného odkladu požadovat provedení dodatečné kontroly, je však povinen zhotoviteli nahradit náklady způsobené opožděním kontroly.

Při provádění díla může $\mathrm{v}$ jednotlivých etapách docházet $\mathrm{k}$,zakrývání prací““. „Zakrývání prací“ je jedním z př́ípadů, kdy je třeba provést kontrolu na určitém stupni jeho provádění. Pozvání objednatele (výzva objednateli) a povinnost účasti objednatele při "zakrývání prací" obvykle mívá zvláštní smluvní ujednání.

Podle rozsahu výstavby je podle našeho názoru vhodné dohodnout ve smlouvě výkon technického dozoru a rozsah oprávnění konkrétních zástupců objednatele a zhotovitele $\mathrm{k}$ činnostem probíhajícím prímo na stavbě.

Rovněž považujeme za vhodné konkretizovat podrobnosti vedení stavebního (montážního) deníku, a to v souladu s úpravou stavebního zákona a jeho prováděcích předpisů. Připomeňme jen, že se deník vede zásadně ode dne zahájení prací na staveništi až do dne ukončení prací a odstranění všech vad.

Deník slouží k zaznamenávání všech důležitých (resp. dalších dohodnutých) skutečností a okolností týkajících se výstavby a může mimo jiné sloužit jako významný důkazní prostř̌edek. Do deníku pak provádějí zápisy i orgány státního stavebního dohledu a orgány státní správy obecně. Deník slouží také jako běžný komunikační prostředek při zajištění spolupơsobení smluvních stran na stavbě. Základní otázky stavebního deníku upravuje dnes př́lloha vyhlášky o dokumentaci staveb.

\section{Skryté překážky, předání stavby}

\subsection{Skryté překážky}

Zjistí-li zhotovitel podle $\S 2627$ při provádění díla skryté překážky týkající se místa, kde má být dílo provedeno, znemožňující provést dílo dohodnutým způsobem, oznámí to bez zbytečného odkladu objednateli a navrhne mu změnu díla. Do dosažení dohody o změně díla může jeho provádění přerušit. 
Nedohodnou-li se strany na změně smlouvy v přiměřené lhůtě, může kterákoli $\mathrm{z}$ nich od smlouvy odstoupit. Zhotovitel má právo na cenu za část díla provedenou do doby, než překážku mohl při vynaložení potřebné péče odhalit.

Tato právní úprava počitá se skrytými překážkami při provádění díla. Na rozdíl od úpravy předchozí (v obchodním zákoníku), může jít jen o překážky týkající se místa, kde má být dílo provedeno.

Současně musí být splněny podmínky

- je znemožněno provést dílo dohodnutým způsobem

- oznámení bylo provedeno bez zbytečného odkladu a byla navržena změna díla.

Do dosažení dohody o změně může zhotovitel provádění přerušit. Jestliže se strany nedohodnou v přiměřené lhůtě, může zhotovitel nebo objednatel od smlouvy odstoupit.

Zhotovitel by pak měl právo na cenu za část díla za splnění zákonné podmínky (do doby než mohl překážku při vynaložení potřebné péče odhalit).

Je zřejmé, že u smlouvy o dílo se občan. zák. nechal inspirovat především dřívější úpravou obchod. zák.

\subsection{Předání stavby, společná odpovědnost určených osob}

Velmi kladně hodnotíme úpravu $\S 2628$ o převzetí stavby. Zde se určuje, že objednatel nemá právo odmítnout převzetí stavby pro ojedinělé drobné vady, které samy o sobě ani ve spojení s jinými nebrání užívání stavby ani funkčně nebo esteticky, ani jejímu užívání podstatným způsobem neomezují.

U staveb se totiž ojedinělým drobným vadám (např. u nátěrů) nelze prakticky vyhnout. Ostatně i zahraniční úpravy s tím počítají (např. v podmínkách pro provádění staveb v Německu); z reality vycházela již i úprava Hospodářského zákoníku, která byla širší a týkala se i ojedinělých drobných nedodělků. Obchodní zákoník, který - pokud si to strany nedohodly - takové ustanovení neobsahoval, se jevil př́liš prrísný. Zdůrazněme však, že musí jít jen o vady ustanovením $\S 2628$ definované.

Otázku připadných drobných nedodělků je možno řešit vhodnou úpravou smluvní.

Kdy jsou se zhotovitelem zavázány společně a nerozdílně i jiné osoby a kdy se zhotovitel zprostí „povinnosti za vady stavby“ upravuje ustanovení § 2630.

Ustanovení $\S 2630$ upravuje společnou a nerozdílnou odpovědnost určených osob spolu se zhotovitelem.

Jedná se o

- poddodavatele zhotovitele

- toho, kdo dodal stavební dokumentaci,

- toho, kdo prováděl stavební dozor.

Poddodavatel však neodpovídá, pokud prokáže, že vadu způsobilo jen rozhodnutí zhotovitele nebo toho, kdo nad stavbou vykonával dozor.

Ten, kdo dodal stavební dokumentaci neodpovídá, prokáže-li, že vadu nezpůsobila chyba ve stavební dokumentaci.

Ten, kdo prováděl dozor neodpovídá, pokud prokáže, že vadu stavby nezpůsobilo selhání dozoru. 
Zhotovitel se pak zprostí odpovědnosti z vady stavby, prokáže-li

- Že vadu způsobila jen chyba ve stavební dokumentaci, dodané osobou, kterou si zvolil objednatel,

- došlo jen k selhání dozoru nad stavbou, kterou si zvolil objednatel.

Spočívá-li dílo v jiném výsledku činnosti, než je zhotovení věci nebo údržba, oprava či úprava věci, postupuje zhotovitel při této činnosti, jak bylo ujednáno a s odbornou péčí tak, aby dosáhl výsledku činnosti určeného ve smlouvě.

Je tedy určeno, že dílem může být i jiný výsledek činnosti; může to být např. programové vybavení, projektová dokumentace či jiná dokumentace.

\section{Dílo s nehmotným výsledkem}

Výsledek činnosti, tj. dílo s nehmotným výsledkem, se odevzdá objednateli; považuje se za předané:

- je-li dokončeno,

- zhotovitel umožní objednateli jeho užití.

Výsledek činnosti, který je předmětem práva průmyslového nebo jiného duševního vlastnictví, může zhotovitel poskytnout i jiným osobám než objednateli, bylo-li tak ujednáno. Neobsahuje-li smlouva výslovný zákaz tohoto poskytnutí, je k němu zhotovitel oprávněn, není-li to vzhledem k povaze díla v rozporu se zájmy objednatele.

Rozhodující pro poskytnutí výsledku jiným osobám je ujednání stran.

Pokud to ujednáno nebylo a smlouva neobsahuje výslovný zákaz poskytnutí, může ho zhotovitel dalším osobám poskytnout, není-li to vzhledem $\mathrm{k}$ povaze díla v rozporu se zájmy objednatele. Lze i zde jen doporučit vhodné ujednání stran.

Je-li předmětem díla výsledek činnosti, který je chráněn právem průmyslového nebo jiného duševního vlastnictví, má se za to, že jej zhotovitel poskytl objednateli k účelu vyplývajícímu ze smlouvy.

Jak vidíme, zde je formulována vyvratitelná domněnka, že výsledek zde určené činnosti byl zhotovitelem poskytnut objednateli k účelu vyplývajícímu ze smlouvy. Rovněž v těchto př́ípadech je vhodné doporučit vhodné ujednání stran.

Ustanovení o díle v NOZ též určuje, že ustanovení oddílu o dílech s nehmotným výsledkem se použijí obdobně i pro výsledek činnosti zhotovený podle ustanovení o veřejném příslibu (soutěžní dílo).

\section{Závěrem}

Příznivý průběh obchodních případů, realizace, popř. aplikace právních ustanovení je podle našeho názoru limitován zejména úrovní právních předpisů, úrovní obsahu smluv i kvalitním dokladováním průběhu plnění smlouvy a rychlostí a kvalitou rozhodování případných sporů.

Význam vhodného smluvního ujednání (žrejmý z našeho pojednání) ve smlouvě o dílo vyplývá ze široké smluvní volnosti, kterou zákon umožňuje a ze skutečnosti, že dílčí okruhy problémů zákoník neřeší a ponechává je smluvním partnerům k jejich volbě (např. dodávky náhradních dílů, servis, délky záruk, sankce, fakturace, placení, zkoušky, převzetí, spolupráci, podrobnosti vedení stavebního či montážního deníku apod.). 
Rozhodující význam přitom má výběr smluvního partnera a vhodná volba zajišt’ovacích prostředků.

Investování vč. vhodných smluvních ujednaní bude přitom vycházet z podnikatelských plánů určujících určujících návratnost a ekonomický benefit pro dané subjekty.

\section{Literatura:}

- BEJČEK, J. - ŠILHÁN, J. a kol. 2015. Obchodní smlouvy, Závazky v podnikání. Praha : C. H. Beck, 2015, ISBN 978-80-7400-574-9.

- ELIÁŠ, K. 2012 Nový občanský zákoník s aktualizovanou důvodovou zprávou a rejstřikem. Ostrava : Sagit, 2012.

- ELIÁŠ, K. - ZUKLÍNOVÁ, M. 2001. Principy a východiska nového kodexu soukromého práva. Praha : Linde Praha, a.s., 2001.

- DVOŘÁK, K. - FIALA, J. - ŠVESTKA, J. 2014. Občanský zákoník, Komentářr, svazek V a svazek VI. Praha : Wolters Kluwer ČR, 2014, ISBN 978-80-7478- 9.

- KLEE, L. 2011. Smluvní podmínky FIDIC. Praha : Wolters Kluwer, 2011., ISBN 978-80-7357-620-2.

- KLEE, L. 2015. Stavební smluvni právo. Praha : Wolters Kluwer ČR, 2015.

- KLEE, L. 2015. International Construction Contract Law. Wiley Blackwell in 2015, ISBN 978-11-1871-790-5.

- KRÁlOVÁ, K. - MAREK, K. 2021. Obchodní podmínky, vykládací pravidla, obchodní zvyklosti. In Acta Iuridica Sladkoviciensia XVII, 2021, s.135-152, ISBN 978-80-7392-36

- MAREK, K. 2008. Smluvni obchodní právo. Kontrakty. 4.vyd. Brno : Masarykova univerzita, 2008, ISBN 978-80-210-4619-1.

- PLÍVÁ, S. - ŠTENGLOVÁ, I. - TOMSA, M. 2010. Obchodní zákoník, Komentář. 12. vydání, Praha : C. H. Beck, 2010.

- OVEČKOVÁ, O. a kol. 2005. Obchodný zákonník, Komentár. 2. vyd., IURA EDITION, 2005.

- OVEČKOVÁ, O. 2007. Povinnost' vykonat' dielo a povinnost' zaplatit cenu na základě zmluvy o dielo podl'a obchodného zákonníka. In Bulletin slovenskéj advokácie. č. 1-2/2007.

- RABAN, P. 2020. Obchodní právo. 1.vyd. Brno : Václav Klemm, 2020, ISBN 978-80-87713-19-8

- SUCHOŽA, J. - HUSÁR, J. - MAREK, K. - RABAN, P. 2011. Česko-slovenské kontexty obchodního práva. 1. vyd. Praha : Wolters Kluwer ČR, 2011, ISBN 97880-7357-707-0.

\section{Judikatura:}

- Rozhodnutí Nejvyššího soudu 29 Cdo 2173/99

Na platnost smlouvy o dílo nemá vliv, že byla uzavřena v době, kdy již byly některé práce provedeny.

- Rozhodnutí Nejvyššího soudu 29 Odo 14/2001

Není-li předepsána nebo některým z účastníků požadována ( $\$ 272$ odst. 1 obch. zák.), písemná forma smlouvy, není vyloučeno, aby ji účastníci uzavřeli zčásti 
písemně a zčásti ústně. Pro hodnocení jednání účastníků je rozhodující jejich vůle při uzavírání smlouvy.

To, že účastníci písemně uzavřené smlouvy o dílo výslovně neprohlásili, že její součástí je i listina připojená ke smlouvě, v níž je vymezen předmět díla, nezpůsobuje neplatnost smlouvy, jestliže se účastníci ústně dohodli, že předmětem smlouvy je dílo vymezené v této listině.

Pozn.: Problematiku $§ 272$ obchod. zák. upravuje $§ 1756$ - 1758 občan. zák.

- Rozhodnutí Nejvyššího soudu 29 Odo 50/2001

Jako zaviněné porušení povinnosti zakládající právo objednatele na zaplacení smluvní pokuty (jestliže účastníci smlouvy o dílo uzavřené podle obchodního zákoníku sjednali smluvní pokutu za zaviněné porušení povinnosti) lze zhotoviteli přičítat i zaviněné porušení povinnosti jeho subdodavatelem.

- Rozhodnutí Nejvyššího soudu 32 Odo 835/2002

Součástí ceny je i daň z prridané hodnoty a clo, nevyplývá-li z dohody stran něco jiného. Není-li stranami dohodnuto něco jiného, nelze dohodnutou cenu díla zvyšovat o daň z přidané hodnoty.

- Rozsudek Nejvyššího soudu 29 Odo 846/2003

Podle ustanovení § 542 odst. 1 obch. zák. lze výhradu vlastnického práva zhotovitele k nemovitosti zhotovované pro objednatele na základě smlouvy o dílo (uzavřené ve smyslu $§ 536$ a násl. obch. zák.) sjednat jen předtím, než došlo ke vzniku vlastnického práva objednatele ke zhotovovaným věcem.

Je-li výhrada vlastnického práva zhotovitele $\mathrm{k}$ nemovitosti zhotovované pro objednatele na základě smlouvy o dílo (uzavřené ve smyslu $§ 536$ a násl. obch. zák.) vázána jen na úplnou úhradu sjednaných záloh na cenu díla, nemůže být zhotovitelem bez dalšího uplatněna poté, co mu v souvislosti s předáním díla vznikl nárok na cenu díla.

Pozn.: Problematiku § 542 až 545 obchod. zák. upravuje $§ 2599$ - 2603 občan. zák.

- Rozhodnutí Nejvyššího soudu 32 Odo 253/2005

Zhotovitel stavby je povinen při zhotovování díla při vynaložení minimální odborné péče rozpoznat v průběhu výstavby podstatnou vadu objednatelem předané dokumentace a na tuto vadu objednatele upozornit.

- Rozhodnutí Nejvyššího soudu 32 Odo 296/2005

Nepředá-li zhotovitel dílo objednateli způsobem ve smlouvě o dílo sjednaným, nenastane splatnost ceny díla a objednatel není v prodlení s úhradou ceny díla, tudíž není ani povinen zaplatit smluvní pokutu, protože neporušil povinnost zaplatit cenu díla ve lhůtě splatnosti

- Rozsudek Nejvyššího soudu 32 Odo 576/2005, 32 Odo 760/2005

Na rozdíl od provedení díla, které zahrnuje řádné ukončení a předání předmětu díla objednateli v místě stanoveném podle $\S 554$ obch. zák., pouhé předání předmětu díla nezahrnuje jeho řádné ukončení, tzn. že ke vzniku nároku na zaplacení ceny ve vazbě na předání díla je zásadní, kdy bylo dílo řádně a bez vad ukončeno.

Pozn.: Problematiku § 554 a 555 obchod. zák. upravuje § 2604 až 2608 občan. zák.

- Rozsudek Nejvyššího soudu 32 Odo 1387/2005

Jestliže zhotovitel dodal vědomě vadné dílo (např. použil pro výrobu díla materiál jiných vlastností, než určovala smlouva, aniž by došlo ke změně smlouvy), 
tj. o vadách musel vědět nebo věděl, je jeho odpovědnost posuzována přísněji a nemůže uplatnit námitku, že kupující neoznámil vady včas.

Za zjevné vady je možno považovat jen takové vady, jejichž existence je kupujícímu, popř. objednateli, zřejmá na pohled, popřr. takové vady, které lze zjistit běžně prováděnými zkouškami. Za zjevné vady proto nelze považovat ty vady, jejichž existenci by musel kupující nebo objednatel zjišt'ovat prohlídkou spojenou s destrukcí zboží nebo díla, popř. vady, které se typicky mohou v plné míre projevit až při užívání zboží nebo předmětu díla.

- Rozhodnutí Nejvyššího soudu 32 Odo 4502/2007

Rozhodnutí o povolení užívání díla (stavby) nenahrazuje samo o sobě předání díla objednateli.

- Rozhodnutí Nejvyššího soudu 32 Odo 542/2008

Neopatřil-li objednatel včas stavební povolení, neposkytl tím potřebné spolupůsobení, aby zhotovitel mohl splnit svůj závazek, tj. dokončit dílo řádně a včas.

- Rozhodnutí Nejvyššího soudu 23 Odo 1242/2008

Věritel se může mj. dostat do prodlení, pokud dlužníkovi neposkytne spolupůsobení, které je nutné k tomu, aby byl dlužník vůbec schopen smluvené plnění poskytnout. Součinnost věřitele může být sjednána ve smlouvě, což však není nezbytnou podmínkou po posouzení toho, zda určitá součinnost věřitele bránila splnění dlužníkova závazku. Vždy půjde o posouzení toho, zda určitá součinnost věřitele je objektivně nutná k tomu, aby dlužník mohl splnit svůj závazek.

\section{Summary: More to the Work Contract}

In connection with the development of industry, the industirial revolution 4.0 and the elimination of the consequences of the coronary crisis, the development of investment can be expected.

The article deals with business practices, essential and non-essential matters of the contract,

FIDIC conditions, rights and obligations of the parties. It also deals with the time of performance, the subject of the work and the price. He points out that the choice of contract is very important partner and careful conclusion of the contract.

prof. JUDr. Karel Marek, CSc.

Výsoká škola finanční a správní

Fakulta právních a správních studií

Estónska 500, 10100 Praha 10

Česká republika

e-mail: k.marek@centrum.cz 